gallery of geology has been opened, and the famous series of Lias and Inferior Oolite ammonites in the Tutcher Collection classified and labelled. Popular study of botany has been encouraged by the wild plant table throughout three of the seasons, while even winter had its offering of displays of twigs. British birds and their nests have been prepared for exhibition, while for students accessions include skins of mammals and birds from the region and the Marle collection of shells, many from the district.

The work of the department of archæology ranges from salving small Romano-British relics to erecting "an unclimbable fence" around the Roman villa at Kings Weston, and one wonders if there is any connexion between this and the reference to the unruly behaviour of certain young visitors on Sunday afternoons-a time-honoured complaint that belies "The better the day, the better ....". Bristol played its part during the year by organizing an administration course for students for the Museums Association diploma, and in its turn sending members of its own staff to technical courses elsewhere. Twenty major temporary exhibitions were staged in the Museum, 3,420 cases of specimens were circulated to schools, etc., and 8,118 children attended for lessons-an entirely creditable performance.

The little handbook to Stratford Mill, costing sixpence, gives on art paper some five pages of text on the history and mechanism of corn-mills in general, and this one in particular, together with a photograph of the mill on its new site and an attractive drawing of its working parts. May we have others on the thatched dairy and the gypsy caravan ?

\section{BLUE HILL OBSERVATORY OF HARVARD UNIVERSITY}

$\mathrm{T}$ HE report of the visiting committee to the Blue Hill Meteorological Observatory, Harvard University, Milton, Mass. (Reprint No. 7, 1953), includes the activities of the Observatory over the previous five years. During this period the facilities of the Observatory have had many users, among which may be noticed not only students working on research problems but also a number of Harvard departments, the United States Weather Bureau, the United States Air Force, the Massachusetts Institute of Technology, Clark University, Illinois State Water Survey, American Meteorological Society, Woods Hole Oceanographic Institution, Mt. Wilson Observatory, the Lowell Institute's Cooperative Broadcasting Council Station $W G B H$, and various business corporations and local towns.

The work of the Observatory staff is concerned with the following topics : evaluation of the Blue Hill and other climatic records, especially as indicators of climatic change ; development of statistical aids to the forecasting of snow-storms for Greater Boston; designing and comparing station equipment and exposures; researches concerning clouds and the physics of precipitation; training of graduate students; and improvement of the library and its service. A very complete and mostly automatic record of the weather has been kept since the winter of 1884-85, when it was started by Abbott Lawrence Rotch. A record kept of the temperature in Milton by the Rev. A. Breck from 1849 has supplied further data on temperature conditions, and it appears that during the past hundred years there has been a remarkable amelioration of the climate. In recog. nition of the value of the Observatory's current work on climatology, the United States Weather Bureau is supplying it with standard instruments, broadcasting its monthly data and publishing its records. Under instrumentation is included an account of the work of Dr. Wallace E. Howell and Mr. John H. Conover in designing and testing new instruments for Blue Hill and other institutions. In research on clouds and precipitation, work was carried out at Blue Hill before Schaefer's experiment in November 1946 of dropping solid carbon dioxide on a cloud of supercooled droplets to make snow, and a month after this Dr. W. E. Howell successfully repeated the experiment on Mt. Washington.

Finally, mention must be made of the Observatory's Library, which is widely used by professional meteorologists all over the country, but particularly in the large group in Boston; so great has been the demand for the Observatory's research publications that Blue Hill has always received on an exchange basis the publications of weather services, universities, research stations or institutes and individuals from all over the world.

\section{THE COLLECTION OF DATA FROM FIRMS}

$\mathrm{T}$ THE research workers who need to collect data from firms cover a wide range of studies and use the data for many different purposes. As, nevertheless, they have many difficulties and problems in common, the Acton Society Trust held a conference on April 28 on "The Pitfalls in the Collection of Data from Firms", at which twenty-three research workers attended, drawn from universities, national research organizations, government departments, co-operative research associations and private industry. They included economists, psychologists, sociologists, statisticians and some whose particular speciality it would be hard to define.

After the formal opening of the conference by Mrs. Honor Croome, Dr. T. E. Easterfield (Department of Scientific and Industrial Research) opened the first session with a discussion of some of the main sources of error in data obtained from firms. The firm's own records may not be kept correctly, or may be kept in a form suitable for its own needs but misleading to the research worker. Information supplied in reply to questionnaires is particularly unreliable, as even the simplest question may not fit every case and may be misunderstood in many different ways.

The second morning session was opened by Mr. Stafford Beer (Samuel Fox and Co.), who spoke of the pitfalls found in data by workers doing research inside industry. Many seemingly excellent data are derived from notebooks and scraps of paper filled up by the semi-literate. Measurements may be given a misleading appearance of accuracy by being recorded to too many significant figures. Nomenclature may also be misleading, the same words being used in different senses in different places. But the worst source of error is the pure blunder : Mr. Beer himself recently reached some quite wrong conclusions by analysing a column giving furnace numbers under the impression that it gave the number of ingots in 